\title{
Effication of Viral Nervous Necrosis DNA as Vaccines for Cromileptes altivelis
}

Wiwien Mukti Adriyani ${ }^{1, *}$, Sri Murtini², Alimuddin ${ }^{3}$

1Balai Budidaya Air Payau Situbondo, Jl. Raya Pecaron KM 5, Desa Klatakan, Kecamatan Kendit Kab. Situbondo, East Java, Indonesia.

${ }^{2}$ Department of Veterinary, IPB University, Jl. Raya Dramaga Bogor 16680 West Java, Indonesia ${ }^{3}$ Department of Aquaculture, IPB University, Jl. Raya Dramaga Bogor 16680 West Java, Indonesia *wiwinmukti@gmail.com

${ }^{*}$ Corresponding author

ARTICLE INFO

\section{Keywords:}

Antibody titer

DNA vaccine

Immunity

Survival rate

\section{ABSTRACT}

Viral nervous necrosis (VNN) is a disease that often infects groupers. It has caused mass death in more than 34 species of marine fish. DNA vaccination might become a solution againts the infection. The construction of the pmBA-CP DNA vaccine consisting of the beta-actin promoter of medaka fish (Oryzias latipes) and capsid protein (CP) encoding VNN RNA2 has been made in previous studies. This study aimed to test the efficacy of the pmBA-CP DNA vaccine for VNN. The experiment consisted of two stages, namely (1) detection of anti-VNN antibody induction in vaccinated fish using ELISA, and (2) challenge test for fish vaccinated with the VNN virus. Grouper (body length $8 \mathrm{~cm}$ to $10 \mathrm{~cm}$ ) were divided into two groups with a density of 5 fish $60 \mathrm{~L}^{-1}$. The fish in the first group were vaccinated with pmBA-CP intramuscularly at a dose of $12.5 \mu \mathrm{g}$ per fish, while the second group of fish were not vaccinated. Antibody titer testing was carried out before treatment, and $1 \mathrm{~d}, 7 \mathrm{~d}, 14 \mathrm{~d}, 21 \mathrm{~d}, 28 \mathrm{~d}$, and $35 \mathrm{~d}$ after vaccination. The challenge test was carried out on the $60^{\text {th }}$ day after vaccination. The results showed that the S / P ratio in the vaccinated fish serum was higher than unvaccinated fish at $21 \mathrm{~d}$ to $35 \mathrm{~d}$ post-vaccination. DNA vaccination was able to induce anti-VNN antibodies of grouper. The results of the challenge test for vaccinated fish using VNN virus titer $10^{3.5} \mathrm{FID} 50 / 0.2 \mathrm{~mL}$ showed $60 \%$ of survival rate. Thus, the pmBA-CP DNA vaccine could be useful for increasing grouper immunity, and support production of grouper.

How to cite:

Andriyani WM, Murtini S, Alimuddin. 2020. Effication of Viral Nervous Necrosis DNA as Vaccines for Cromileptes altivelis. IJOTA, 3(2): 78-86. DOI: https://doi.org/10.22219/ijota.v3i2.13891 


\section{Introduction}

DNA vaccines is an immunization techniques to protect organisms (animals / humans) against various disease agents. DNA vaccination is carried out by providing pure DNA (naked DNA) in the gene construction form to generate an immune response. The expression of antigen proteins in the cells of the vaccinated organisms induces humoral and cellular immune responses, and is relatively long-lasting. The efficacy of DNA vaccines has been proven to infectious hematopoietic necrosis virus (IHNV), viral hemorrhagic septicemia (VHS) (Anderson et al. 2000), Aeromonas veroni (Vazquez-Juarez et al 2005), Vibrio anguillarum (Kumar et al. 2007), and koi herpesvirus (Nuryati et al. 2010). The use of DNA vaccine has various advantages, such as generic and simple, safe and no risk of disease infection. Moreover, it also has advantages for activating the humoral and cellular immune systems against variety of viruses, providing a good protection such as in both low and high temperatures when it is absorbed by fish the initial stage, the protection can be induced in a short time and provides a protective effect in a relatively long time. In addition, DNA vaccine technology provides a vaccine for new pathogens quickly with low cost, the pure DNA vaccine products have high stability, relatively cheap production costs and easy to produce (Lorenzen et al. 2005).

Viral nervous necrosis (VNN) is one of diseases that often infects groupers. The VNN is a virus from the Betadovirus genus with $25 \pm 30 \mathrm{~nm}$ in diameter and no enveloped. They have a core in the form of single-stranded RNA containing two RNA strands, and their genome are icosahedral. The RNA-1 of VNN is about $3.1 \mathrm{~kb}$ encoding RNA polymerase which is responsible for genome replication. Meanwhile, the RNA-2 is about $1.4 \mathrm{~kb}$ encoding capsid protein (CP) (Chi et al. 2001) which is suspected to be an infective protein of the VNN (Lin et al. 2007). As a first step, the construction of a DNA vaccine has been made to prevent infection of VNN virus in groupers. The CP of VNN encoding gene was linked to the $\beta$-actin gene promoter of Japanese medaka fish/mBA (Takagi et al. 1994) to construct the pmBA-CP vaccine (Nuryati et al. 2010). This study aimed to examine the efficacy of the pmBA-CP as a DNA vaccine in increasing the immunity of Cromileptes altivelis against VNN disease.

\section{Material and methods}

\subsection{The VNN antigen preparation}

One gram of brains and eyes of VNN-infected grouper were put into a tube and crushed using a pestle pellet until smooth. One mililiter of phosphate buffer saline (PBS) was added to the sample. Futhermore, the suspension was homogenated by centrifuge at $3000 \mathrm{~g}$ for $10 \mathrm{~min}$. The supernatant was transferred to a new tube, and again centrifuged at $27,000 \mathrm{~g}$ for $20 \mathrm{~min}$. The supernatant was filtered using a $0.22 \mu \mathrm{m}$ filter and stored at $-20^{\circ} \mathrm{C}$ until use (WHO, 2006).

\subsection{DNA vaccine preparation}

Escherichia coli DH5 $\alpha$ containing DNA vaccine were inoculated into 2xYT media (Nuryati et al 2010). The bacteria were incubated and shaken using a shaker at a speed of $250 \mathrm{rpm}$ for $17 \mathrm{~h}$ at $37^{\circ} \mathrm{C}$. DNA vaccine plasmids were isolated from bacteria using conventional methods provided by Sambrook et al (1989) using the illustra plasmidPrep Mini Spin (GE Healthcare) kit according to the manual procedure. Confirmation of the presence of plasmid DNA from these different methods was analyzed using PCR. 


\subsection{Production of polyclonal antibodies}

The polyclonal antibody $(\mathrm{Ab})$ of VNN was produced using one New Zealand rabbit. The first immunization was carried out by subcutaneous route (SC) using VNN suspension emulsified in Freund's adjuvant incomplete. Re-immunization was carried out using the same dose of viral suspension emulsified in Freund's adjuvant incomplete at week 4 and 7. Moreover, 2 weeks after the third immunization, rabbit blood was drawn to check for the existence of VNN Ab from the serum. Detection of VNN Ab in serum used a precipitation test (Agar Gel Precipitation Test / AGPT). The samples were incubated for $30 \mathrm{~min}$ at $37^{\circ} \mathrm{C}$, and then centrifuged at $5000 \mathrm{rpm}$ for $15 \mathrm{~min}$ to harvest $A b$. The serum mixture was re-tested for the presence of VNN Ab by the AGPT test. The positive serum was stored at $-20^{\circ} \mathrm{C}$ until use.

\subsection{Detection of the antibody formation ability of the DNA vaccine}

A total of 70 grouper (body length $8 \mathrm{~cm}$ to $10 \mathrm{~cm}$ ) were divided into two groups with 35 fish each. The first group was vaccinated based on the dose from the second test, and the second group was not vaccinated. The fish blood was drawn from five fish from each treatment before vaccination and at $1 \mathrm{~d}, 7 \mathrm{~d}, 14 \mathrm{~d}, 21 \mathrm{~d}, 28 \mathrm{~d}$ and $35 \mathrm{~d}$ after vaccination. The presence of VNN Ab in serum was tested using the enzyme linked imunnosorbent assay (ELISA) sandwich method (Figure 1). The phosphate buffer saline was used as a negative control, and rabbit serum containing VNN Ab was a positive control. The ab of VNN level was determined based on the S/P ratio with the formula:

$\mathrm{S} / \mathrm{P}$ sampel $=\quad$ (the absorbance of samples)-(the absorbance of positive control) (the absorbance of positive control)-( the absorbance of negative control)

Table 1. Vaccination design for antibody detection

\begin{tabular}{cccccccc}
\hline \multirow{2}{*}{ Treatment } & \multicolumn{7}{c}{ Sampling time (d) } \\
\cline { 2 - 9 } & 0 & 1 & 7 & 14 & 21 & 28 & 35 \\
\hline Vaccinated (ind) & 5 & 5 & 5 & 5 & 5 & 5 & 5 \\
No vaccinated (ind) & 5 & 5 & 5 & 5 & 5 & 5 & 5 \\
\hline
\end{tabular}

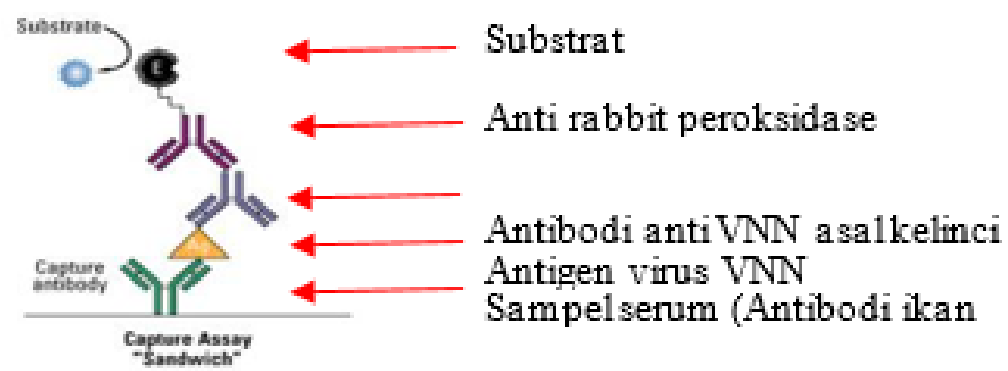

Figure 1. ELISA sandwich principle for detecting the presence of VNN antibodies in grouper serum.

\subsection{Challenge the DNA VNN vaccine}

Vaccination designs and antibody observations are presented in Table 2. The present study used grouper with a size of $13 \mathrm{~cm}$ to $15 \mathrm{~cm}$, as many as 50 individuals divided into 5 groups. Vaccination treatment used the best dose in the previous stage with $12.5 \mu \mathrm{g}$ each fish. The challenge 
test was carried out on the $60^{\text {th }}$ day after vaccination and observed every day during the challenge test. The mortality was recorded daily and calculated from each vaccination treatment and compared with control groups (Nuryati et al. 2010). The relative percent survival (RPS) was calculated by the formula:

Tabel 2. Challenge test designs

\begin{tabular}{lll}
\hline \multicolumn{1}{c}{ Treatment } & \multicolumn{2}{c}{ Repitation (ind) } \\
\hline Negative control (no vaccinated + no PBS) & 1 & 2 \\
Negative control (no vaccinated + PBS) & 5 & 5 \\
Positive control (no vaccinated + VNN) & 5 & 5 \\
Vaccinated with $12,5 \mu$ g each fish (+PBS) & 5 & 5 \\
Vaccinated with $12,5 \mu$ g each fish (+VNN) & 5 & 5 \\
\hline
\end{tabular}

\section{Results and Discussion}

The existence of VNN virus in groupers was detected using the PCR. The isolated VNN as much as $1 \mathrm{~mL}$ with a concentration of $298 \mu \mathrm{g}$ to $371 \mu \mathrm{g} \mathrm{mL}^{-1}$ was used as an antigen. The VNN virus can be used as a considerable antigen for the production of polyclonal Ab. According to Goidl et al (1968), polyclonal Ab in rabbits can be induced by injection as an antigen as much as $25 \mu \mathrm{g}$ to $50 \mu \mathrm{g} \mathrm{kg}^{-1}$ of body weight. Rabbits were immunized with VNN virus suspension at a dose of $33.5 \mu \mathrm{g}$ $\mathrm{kg}^{-1}$ of body weight. The results showed that Ab of VNN in rabbits could be induced by antigens after the $3^{\text {rd }}$ immunization, which was tested using AGPT with the formation of a precipitation line between the antigen and the tested serum (Figure 2). The obtained rabbit serum was absorbed with a protein suspension of grouper eyes and brains free of VNN infection to inactivate Ab against fish protein.

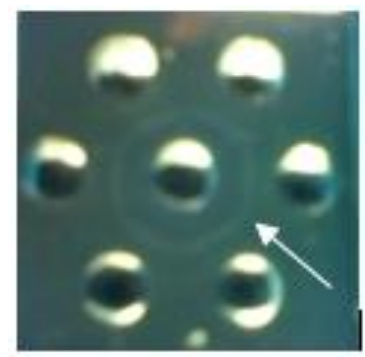

Figure 2. AGPT analysis between VNN antigen and anti VNN rabbit serum. The arrows indicate the position of the precipitation line.

\subsection{Propagation of DNA vaccines}

The cultured $E$. coli reached 2.9 to $3.1\left(\times 10^{9}\right.$ cells $\left.\mathrm{mL}^{-1}\right)$. The concentration of DNA was produced an average of $120.6 \mu \mathrm{g} \mathrm{mL}^{-1}$ with a purity level of isolated plasmid DNA ranging from $76 \%$. PCR results as confirmation of the presence of DNA vaccines showed a DNA band about $1 \mathrm{~kb}$ in all isolated plasmids (Figure 3). This proved that the plasmids contained VNN DNA. 


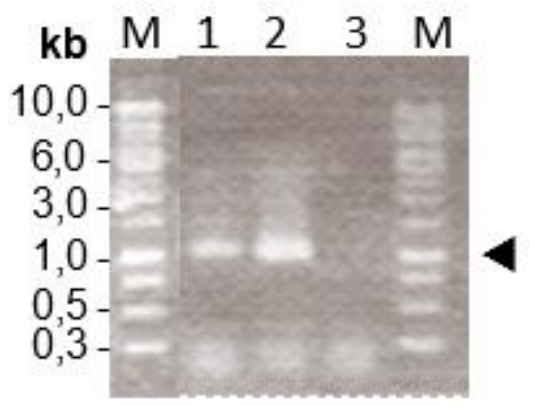

Figure 3. Verification of the isolated pmBA-CP vaccine using a kit and conventional. (M) DNA marker, (1) isolation of pmBA-CP plamid with kit, (2) isolation of conventional pmBA-PCV plamid, and (3) negative control. The arrowheads indicated the position of the VNN DNA fragment.

\subsection{The ability of the $P m B A-C P D N A$ vaccine to induce antibodies}

The grouper was vaccinated with DNA VNN vaccine at a dose of $12.5 \mu \mathrm{g}$ each fish. The presence of anti-VNN antibodies in fish serum was tested by ELISA as shown in Figure 1. The positive ratio values (S/P ratio) are shown in Table 3.

Table 3. Average value of the S/P ratio of fish serum antibodies vaccinated with DNA of VNN and unvaccinated

\begin{tabular}{ccc}
\hline Observation post-vaccination & \multicolumn{2}{c}{ The S/P value from each group } \\
\cline { 2 - 3 }$(\mathrm{d})$ & Vaccinated fish & Unvaccinated fish \\
\hline 1 & $0.274 \pm 0.215^{\mathrm{a}}$ & $0.064 \pm 0.158^{\mathrm{a}}$ \\
7 & $0.428 \pm 0.248^{\mathrm{a}}$ & $0.234 \pm 0.379^{\mathrm{a}}$ \\
14 & $0.596 \pm 0.196^{\mathrm{a}}$ & $0.329 \pm 0.507^{\mathrm{a}}$ \\
21 & $0.680 \pm 0.250^{\mathrm{b}}$ & $0.079 \pm 0.193^{\mathrm{a}}$ \\
28 & $1.325 \pm 0.965^{\mathrm{b}}$ & $0.078 \pm 0.191^{\mathrm{a}}$ \\
35 & $0.788 \pm 0.077^{\mathrm{b}}$ & $0.288 \pm 0.317^{\mathrm{a}}$
\end{tabular}

Note: different superscripts on the same line indicate statistically significant differences $(P<0.05)$.

The ELISA test showed that the serum concentration of vaccinated grouper revealed a higher $\mathrm{S} / \mathrm{P}$ ratio value than the unvaccinated fish on days 21 to 35 after vaccination (Table 3 ). This study indicated that the grouper responded to the antigen on days 21 to 35 . The high absorbance describes the amount of chromogen that changes color due to the large number of products formed by the enzyme reaction with the substrate. This study portrayed the number of enzyme-labeled conjugates bound to rabbit-origin anti-VNN antibodies that bind to VNN antigen. The amount of VNN antigen bound to the VNN antibody from rabbits was proportional to the amount of VNN antibody from the serum of tested grouper. Thus, the higher S/P ratio, the higher the absorbance of the sample and the more VNN antibodies contained in the tested serum.

The results of statistical analysis of the S/P ratio showed that the value of the S/P ratio of serum antibody of vaccinated fish was significantly different from those that were not vaccinated. Based on the observation of the ELISA test and statistical analysis of the vaccinated fish serum, it showed that the DNA VNN vaccine could induce the formation of antibodies in groupers.

\subsection{Challenge Test}

The challenge test of vaccinated fish using the CP of VNN encoding DNA vaccine could be seen in Table 4. The challenge tests using a dose of $12.5 \mu \mathrm{g}$ were injected intramuscularly using VNN virus filtrate with a VNN virus titer concentration of $103.5 \mathrm{FID} 500.2 \mathrm{~mL}^{-1}$. It was carried out on the 
$60^{\text {th }}$ day after vaccination. The time of the challenge test was still within the range according to the research conducted by Kim et al. (2000). The application of DNA vaccines with glycoprotein gene induced the formation of interferon alpha / beta of rainbow trout at 21 or $70 \mathrm{~d}$ after plasmid injection containing DNA vaccines because interferon alpha / beta acts as a mediator that induces nonimmune responses followed by the formation of a specific immune response so that the protection provided lasts quite a long time.

Table 4. Survival and relative survival of fish after the VNN virus challenge test

\begin{tabular}{lccc}
\hline \multirow{2}{*}{ Treatment } & \multicolumn{3}{c}{ Percentage (\%) } \\
\cline { 2 - 4 } & Mortality & SR & RPS \\
\hline Negative control (no vaccinated + no PBS) & 0 & 100 & - \\
Negative control (no vaccinated + PBS) & 0 & 100 & - \\
Positive control (no vaccinated + VNN) & 100 & 0 & - \\
Vaccinated with $12,5 \mu$ g each fish (+PBS) & 0 & 100 & - \\
Vaccinated with $12,5 \mu$ g each fish (+VNN) & 40 & 60 & 60 \\
\hline
\end{tabular}

The viability of the vaccinated fish was $60 \%$ until the $6^{\text {th }}$ day after the challenge test. Positive control groups showed $100 \%$ mortality that occurred on the $4^{\text {th }}$ day after the challenge test. The mortality of the vaccinated fish was relatively longer 2 days than the positive control. The negative controls groups which were vaccinated were alive $100 \%$ until the end of the study, as were the other negative controls without vaccination and challenge test. These results indirectly indicated that vaccination with the DNA of VNN vaccine increased fish survival rate compared to fish without vaccination. This occurred because the vaccinated fish with the DNA of VNN vaccine at a dose of $12.5 \mu \mathrm{g}$ each fish produced CP VNN antigenic protein and this protein could activate the immune response. This vaccine induced immune response causes the fish to be able to produce antibodies, so that when there is a VNN virus infection, the vaccinated fish are able to neutralize the virus. As a result of the neutralization of these antibodies, some of the infected viruses did not succeed in infecting so that the fish survived longer than fish that were not vaccinated.

Research by Nuryati et al. (2010) showed that vaccinating fish with the KHV glycoproteinencoding DNA vaccine at a dose of $12.5 \mu \mathrm{g}$ at $24^{\circ} \mathrm{C}$ resulted $96.7 \%$ of survival rate up to $30 \mathrm{~d}$ after the challenge test. The time interval between the challenge test and the death of the fish is very different from the challenge test results in this study. The mortality conditions of vaccinated fish with DNA VNN and control fish showed a time difference of $2 \mathrm{~d}$ to $6 \mathrm{~d}$ after vaccination. This time difference may be related to the viral dose used and viral infectivity. According to Nuryati et al. (2010), the dose of the virus used affects on the time interval between the challenge test and fish mortality. The VNN virus resulted from reinfection of grouper is suspected to have high viral infectivity at a titer of $10^{3.5} \mathrm{FID}_{50} 0.2 \mathrm{~mL}^{-1}$ so that the challenge test treatment needed to be diluted.

Our results showed that the vaccination treatment at a dose of $12.5 \mu \mathrm{g}$ produced RPS in the range of successful vaccination tests, RPS is greater than $50 \%$ (Emmenegger et al. 2008). The use of the DNA vaccine encoding the SVCV virus glycoprotein gene in koi fish in North America resulted in an RPS value of $50 \%$ to $88 \%$ and was declared a successful vaccination test (Emmenegger and Kurath 2008). These studies proved that the DNA vaccine can induce antibodies that are specific and protective against SVCV disease. Research by Sommerset et al. (2003), the use of the DNA vaccine encoding the glycoprotein virus septicemia virus (VHSV) injected intramuscularly into turbot fish, then challenged with the Atlantic halibut stainvirus (AHNV) virus genus Nodavirus $\left(1 \times 10^{6.3}\right.$ $\mathrm{TCID}_{50}$ ) showed that fish immune response was more induced early and lasts longer. Immune 
response was seen $8 \mathrm{~d}$ after vaccination. The cumulative mortality rate was $54 \%$ up to $26 \mathrm{~d}$ post challenge test.

Compared to other VNN vaccines, the use of the VNN DNA vaccine had the same good efficiency when viewed from the resulting RPS value, which was $60 \%$. The death condition of vaccinated fish with DNA of VNN compared with control fish was a difference of $2^{\text {nd }} \mathrm{d}$ to the $6^{\text {th }}$ day after the challenge test, but the mortality of the vaccinated fish was relatively longer $2 \mathrm{~d}$ than unvaccinated fish. The use of inactivated vaccines for sunu grouper (Epinephelus coioides) by Pakingking et al. (2010), which were injected intraperitoneally as much as $100 \mu \mathrm{L}$ of inactive VNN virus showed significantly different challenge test results $(p<0.001)$ between groups of fish vaccinated with VNN virus $10^{6.5} \mathrm{TCID}_{50}$ compared to fish without vaccination. The resulting RPS values ranged from $86 \%$ to $100 \%$. Meanwhile, the use of the coat proteins recombinant of VNN virus vaccine in groupers at a dose of $0.21 \mathrm{mg}$ intramuscularly 2 times with an interval of $10 \mathrm{~d}$ showed that fish mortality began on the $4^{\text {th }} \mathrm{d}$ and all fish died on the $7^{\text {th }}$ day after the challenge test with VNN virus dose of $10^{5.5} \mathrm{TCID}_{50}$ intramuscularly. Vaccinated fish also showed mortality from day 5 after the challenge test with a lower cumulative mortality rate (mean $32.5 \%$ ) (Yuasa et al. 2002). Thus, the results of the challenge test on intramuscular vaccination using the $12.5 \mu \mathrm{g}$ of the pmBACP DNA vaccine showed that the vaccine was able to increase the immunity of grouper against VNN infection.

Administration of VNN DNA vaccine through feed and immersion is the recommended application method for mass vaccination of fish on a field scale, and this needs further investigation. This method has been evaluated for its effectiveness in a study by Kai et al. (2008) which was used an inactivated betanodavirus vaccine by immersion method. The results showed that RPS was greater than $75 \%$ after the challenge test using VNN virus concentration of $10^{6} \mathrm{TICD}_{50} \mathrm{~mL}^{-1}$. In other study, vaccination was applied through natural feed which resulted in $64.2 \%$ and $69.5 \%$ of RPS after the challenge test with VNN $10^{5}$ TCID $_{50}$ virus intra-peritoneally (Lin et al. 2007).

\section{Conclusion}

The VNN pmBA-CP DNA vaccine was able to induce anti-VNN antibodies at $21 \mathrm{~d}$ after vaccination. The vaccine at a dose of $12 \mu \mathrm{g}$ was effective in inducing the immune grouper against VNN infection.

\section{References}

Anderson E D, Leong J-A C. 2000. Development of DNA vaccines for salmonid fish. In DNA Vaccines (pp. 105-121): Springer.

Chi S, Lo B, Lin S. 2001. Characterization of grouper nervous necrosis virus (GNNV). Journal of Fish Diseases 24(1): 3-13. https://doi.org/10.1046/j.1365-2761.2001.00256.x

Emmenegger E J, Kurath G. 2008. DNA vaccine protects ornamental koi (Cyprinus carpio koi) against North American spring viremia of carp virus. Vaccine 26(50): 6415-6421. https://doi.org/10.1016/j.vaccine.2008.08.071 
Goidl E A, Paul W E, Siskind G W, Benacerraf B. 1968. The Effect of Antigen Dose and Time after Immunization on the Amount and Affinity of Anti-Hapten Antibody. The Journal of Immunology 100(2): 371-375.

Kai Y-H, Chi S-C. 2008. Efficacies of inactivated vaccines against betanodavirus in grouper larvae (Epinephelus coioides) by bath immunization. Vaccine 26(11): 1450-1457. https://doi.org/10.1016/j.vaccine.2007.12.043

Kim C H, Johnson M C, Drennan J D, Simon B E, Thomann E, Leong J A. 2000. DNA vaccines encoding viral glycoproteins induce nonspecific immunity and $M x$ protein synthesis in fish. Journal of virology 74(15): 7048-7054. 10.1128/jvi.74.15.7048-7054.2000

Kumar S R, Parameswaran V, Ahmed V P I, Musthaq S S, Hameed A S S. 2007. Protective efficiency of DNA vaccination in Asian seabass (Lates calcarifer) against Vibrio anguillarum. Fish \& Shellfish Immunology 23(2): 316-326. https://doi.org/10.1016/j.fsi.2006.11.005

Lin C-C, Lin J H-Y, Chen M-S, Yang H-L. 2007. An oral nervous necrosis virus vaccine that induces protective immunity in larvae of grouper (Epinephelus coioides). Aquaculture 268(1): 265273. https://doi.org/10.1016/j.aquaculture.2007.04.066

Lorenzen N, LaPatra S J R S E T-O I D E. 2005. DNA vaccines for aquacultured fish. 24(1): 201.

Nuryati S, Alimuddin A, Sukenda S, Soejoedono R D, Santika A, Pasaribu F H, Sumantadinata K. 2010. Construction of a DNA vaccine using glycoprotein gene and its expression towards increasing survival rate of KHV-infected common carp (Cyprinus carpio). Jurnal Natur Indonesia 13(1): 47-52.

Pakingking R, Bautista N B, de Jesus-Ayson E G, Reyes O. 2010. Protective immunity against viral nervous necrosis (VNN) in brown-marbled grouper (Epinephelus fuscogutattus) following vaccination with inactivated betanodavirus. Fish \& Shellfish Immunology 28(4): 525-533. https://doi.org/10.1016/j.fsi.2009.12.004

Sambrook J, Fritsch E F, Maniatis T. 1989. Molecular cloning: a laboratory manual: Cold spring harbor laboratory press.

Sommerset I, Lorenzen E, Lorenzen N, Bleie H, Nerland A H. 2003. A DNA vaccine directed against a rainbow trout rhabdovirus induces early protection against a nodavirus challenge in turbot. Vaccine 21(32): 4661-4667. https://doi.org/10.1016/S0264-410X(03)00526-7

Takagi S, Sasado T, Tamiya G, Ozato K, Wakamatsu Y, Takeshita A, Kimura M. 1994. An efficient expression vector for transgenic medaka construction. Mol Mar Biol Biotechnol 3(4): 192199.

Vazquez-Juarez R C, Gomez-Chiarri M, Barrera-Saldaña H, Hernandez-Saavedra N, Dumas S, Ascencio F. 2005. Evaluation of DNA vaccination of spotted sand bass (Paralabrax maculatofasciatus) with two major outer-membrane protein-encoding genes from Aeromonas veronii. Fish \& Shellfish Immunology 19(2): 153-163. https://doi.org/10.1016/j.fsi.2004.12.007 
WHO. 2006. Manual of diagnostic tests for aquatic animals. In: OIE Paris

Yuasa K, Koesharyani I, Roza D, Mori K, Katata M, Nakai T. 2002. Immune response of humpback grouper, Cromileptes altivelis (Valenciennes) injected with the recombinant coat protein of betanodavirus. Journal of Fish Diseases 25(1): 53-56. http://dx.doi.org/10.1046/j.13652761.2002.00325.X 